\title{
LEAD DISTRIBUTION IN A SIMULATED AQUATIC ENVIRONMENT: EFFECTS OF BACTERIAL BIOFILMS AND IRON OXIDE
}

\author{
YARROW M. NELSON, WAIHUNG LO, LEONARD W. LION, \\ MICHAEL L. SHULER and WILLIAM C. GHIORSE
}

\begin{abstract}
Biofilms influence the transport and fate of heavy metals in aquatic environments both directly by adsorption and complexation reactions and indirectly via interactions with oxides of iron and manganese. These reactions were investigated by introducing lead into a continuous-flow biofilm reactor that was designed to simulate conditions in a flowing freshwater aquatic environment. The reactor provided controlled conditions, and use of a chemically-defined growth medium allowed calculation of lead speciation with a chemical equilibrium program (MINEQL). Pseudomonas cepacia was employed as a test cell strain because of its ability to grow and form biofilms in the defined medium. This bacterium affected lead distribution in the reactor by adsorbing lead both to adherent and suspended cells. When the aqueous bulk lead concentration was $1.4 \pm 0.1 \mu \mathrm{M}$ and biofilm coverage (measured as chemical oxygen demand, $\mathrm{COD}$ ) was 50 mequiv $\mathrm{COD} / \mathrm{m}^{2}$, lead adsorption was increased by about a factor of five relative to bare glass. Of the total lead in solution, only $1 \%$ was adsorbed to suspended cells $\left(5 \times 10^{7} \mathrm{cells} / \mathrm{ml}\right)$. Lead adsorption to biofilms followed a Langmuir isotherm with a maximum adsorption $\left(\Gamma_{\max }\right)$ of $56 \mu \mathrm{mol}$ $\mathrm{Pb} /$ equiv $\mathrm{COD}$ and an adsorption equilibrium constant $(K)$ of 0.64 liter $/ \mu \mathrm{mol} \mathrm{Pb}$. Lead complexed with dissolved bacterial exopolymer was below detection limits. Pretreatment of glass slides with colloidal iron also significantly increased lead adsorption relative to bare glass. Lead adsorption to adsorbed iron fit a Langmuir isotherm with $\Gamma_{\max }=50 \mu \mathrm{mol} \mathrm{Pb} / \mathrm{mol} \mathrm{Fe}$, and $K=1.3$ liter $/ \mu \mathrm{mol} \mathrm{Pb}$. Lead binding to glass coated with both cells and iron was additive, and could be predicted by summing adsorption predicted using isotherms for each constituent. The presence of iron surface coatings increased initial biofilm formation rates, but after reaching steady state conditions, biofilm coverage was similar for slides treated with iron and untreated slides. A concentration of $1 \mu \mathrm{M}$ lead produced a transient reduction in suspended cell counts. Cell counts recovered to the original cell density over the course of five to ten reactor retention times. With iron present, the magnitude of the reduction in cell concentration in response to the addition of lead was greatly reduced, suggesting that toxic effects of lead may be reduced by iron.
\end{abstract}

Key words-adsorption, aquatic, environment, bacteria, biofilms, bioreactor, biopolymer, complexation, extracellular polymer, iron oxide, lead

\section{INTRODUCTION}

The toxicity of lead and other heavy metals has prompted great interest in their transport and fate in aquatic environments. The cycling of these metals in both freshwater and marine environments has been attributed to their binding to iron and manganese oxides, adsorption to suspended organic materials and complexation with dissolved organic materials (Turekian, 1977). Some researchers have reported that metal oxides are the single most important determinant of trace metal adsorption (Kruaskopf, 1956; Jenne, 1968), while others have reported that organic materials are more important because of their high active surface area (Balistrieri and Murray, 1983; Sigg, 1985). A number of laboratory studies have indicated that lead is predominantly associated with ferromanganese coatings (Carpenter et al., 1975; Whitney, 1975; Lion et al., 1982). However, significant fractions of lead have also been reported to be associated with organic materials in natural aquatic environments (Brundin and Nairis, 1972; Cooper and Harris, 1974). The relative significance of biotic vs abiotic factors as controls for trace metal cycling is expected to be influenced by conditions in the aqueous environment as well as the nature of the trace metal itself. Lion et al. (1982) found that $70 \%$ of extractable lead from estuarine sediments was associated with $\mathrm{Fe}$ and $\mathrm{Mn}$ oxides, while $50 \%$ of the total extractable cadmium was associated with an organic phase. Also, Luoma and Bryan (1981) reported that iron was important in binding $\mathrm{Ag}, \mathrm{Cd}$, $\mathrm{Cu}, \mathrm{Pb}$ and $\mathrm{Zn}$, while humic materials were important in binding $\mathrm{Ag}$ and $\mathrm{Cu}$.

Clearly, the binding of trace metals to both metal oxides and organic materials needs to be considered 
when examining the fate of these trace metals in the environment. Indeed, the ubiquity of bacteriadominated and ferromanganese-containing biofilms and flocculent particles in aquatic environments suggests that trace metal binding to these materials may be the most important factor governing trace metal transport in such environments. Physical removal of trace metals to sediments in natural environments and to sludges in engineered environments is therefore expected to be governed by adsorption, flocculation, and settling of these materials. Such transport is expected to be further influenced by the interactions between the metal oxides and biogenic material, as first suggested by Jenne (1968). Jenne reported that biogenic materials indirectly affect heavy metal availability via their control of hydrous oxides. A conceptual model of possible interactions of trace metals with surfaces and suspended and dissolved organic materials is shown in Fig. 1. First, suspended organic material and biofilms can adsorb trace melals directly, and thus compete with adsorption at the oxide surface binding sites. Findings from laboratory experiments have indicated that bacteria have significant binding capacities for lead (Harvey and Leckie, 1985; Lion et al., 1988; Lion and Rochlin, 1989). Second, organic materials can adsorb to oxide surfaces and alter subsequent trace metal adsorption. Such organic materials could be in the form of biofilms on oxide surfaces or adsorbed organic ligands. These surface coatings can mask the properties of the underlying surface by changing the surface charge or by occupying adsorption sites of the oxide surface (Hunter and Liss, 1979; Davis, 1982; Tipping and Cooke, 1982). Complexing ligands can also adsorb to surfaces and increase metal adsorption (Davis and leckie, 1978). Third, dissolved biogenic organic material can form complexes with metals in solution. For example, extracellular polymers produced by bacteria have been reported as important ligands for complexing trace metals (Corpe, 1975; Rudd et al., 1984). Trace metal-organic complexes can also adsorb to oxide surfaces as a unit, and their adsorption behaviour may be different than that of the free metal ion. Fourth, biofilms and suspended organic materials can indirectly influence trace metal adsorption by altering the deposition of metal oxides to surfaces. This influence could be

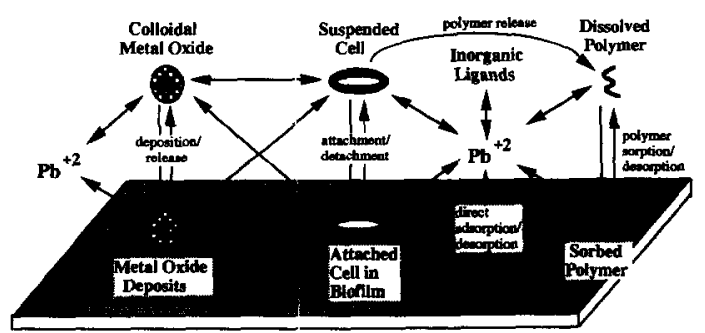

Fig. 1. Interactions between metal oxide surfaces and biogenic organic materials affecting trace metal binding. passive, through alteration of the surfaces to which the oxides are depositing, or it could be active through the biological mediation of iron or manganese oxide deposition (Ghiorse, 1984; Lion et al., 1988). Additionally, metal oxides bound to surfaces could influence subsequent cell adhesion and the formation of biofilms by altering the surface charge, nutrient concentration or other micro-environmental factors affecting colonization by bacteria.

The complexity of the adsorption processes and their interactions, as well as the diversity of biofilmforming bacteria and the variability of the chemical composition of natural waters, has led to difficulties in developing useful models for predicting the distribution of heavy metals in natural environments. Studies using natural aquatic environments are ultimately limited by the large number of uncontrolled variables. On the other hand, most laboratory experiments using well-defined components have been too simplified to permit meaningful extension to natural systems. Many laboratory studies have evaluated trace metal adsorption to inorganic surfaces without consideration of the modification of surfaces by biogenic materials. A useful compromise would be to conduct laboratory studies with greater complexity than used in previous laboratory studies, while still maintaining sufficient experimental control to study the chemical and biological mechanisms underlying the observed effects.

In the present work, a biofilm reactor system (Hsieh et al., 1985) was used for studying trace metal interactions with metal oxides and biogenic materials in a well-controlled laboratory environment. Experiments were used to investigate lead adsorption to biological materials, including attached biofilms, suspended cells, and biopolymers produced by the test bacterium, Pseudomonas cepacia. Lead adsorption to surfaces modified with iron oxide was also evaluated, and the interactions between iron oxides and biofilms were investigated in terms of lead adsorption. Lead toxicity to $P$. cepacia was also investigated both in the absence and presence of iron.

The reactor system used in this work permits accurate and independent control of hydraulic retention time (via feed rate) and Reynolds number (via recycle rate), as well as temperature and $\mathrm{pH}$. A dilute, defined medium was employed so that lead speciation could be estimated using MINEQL, a chemical equilibrium computer program (Westall et al., 1976). The reactor was operated under sterile conditions and inoculated with a pure culture of $P$. cepacia. $P$. cepacia is predominantly a soil bacterium (Bergey's, 1984) and was chosen based on its ability to form biofilms and grow in the dilute growth medium (Murgel et al., 1991). The adherent properties of $P$. cepacia in the defined medium were expected to mimic those of bacteria in aquatic systems. The use of a pure bacterial culture in these experiments avoided uncertainties that arise from using undefined natural assemblages in which bacterial community 


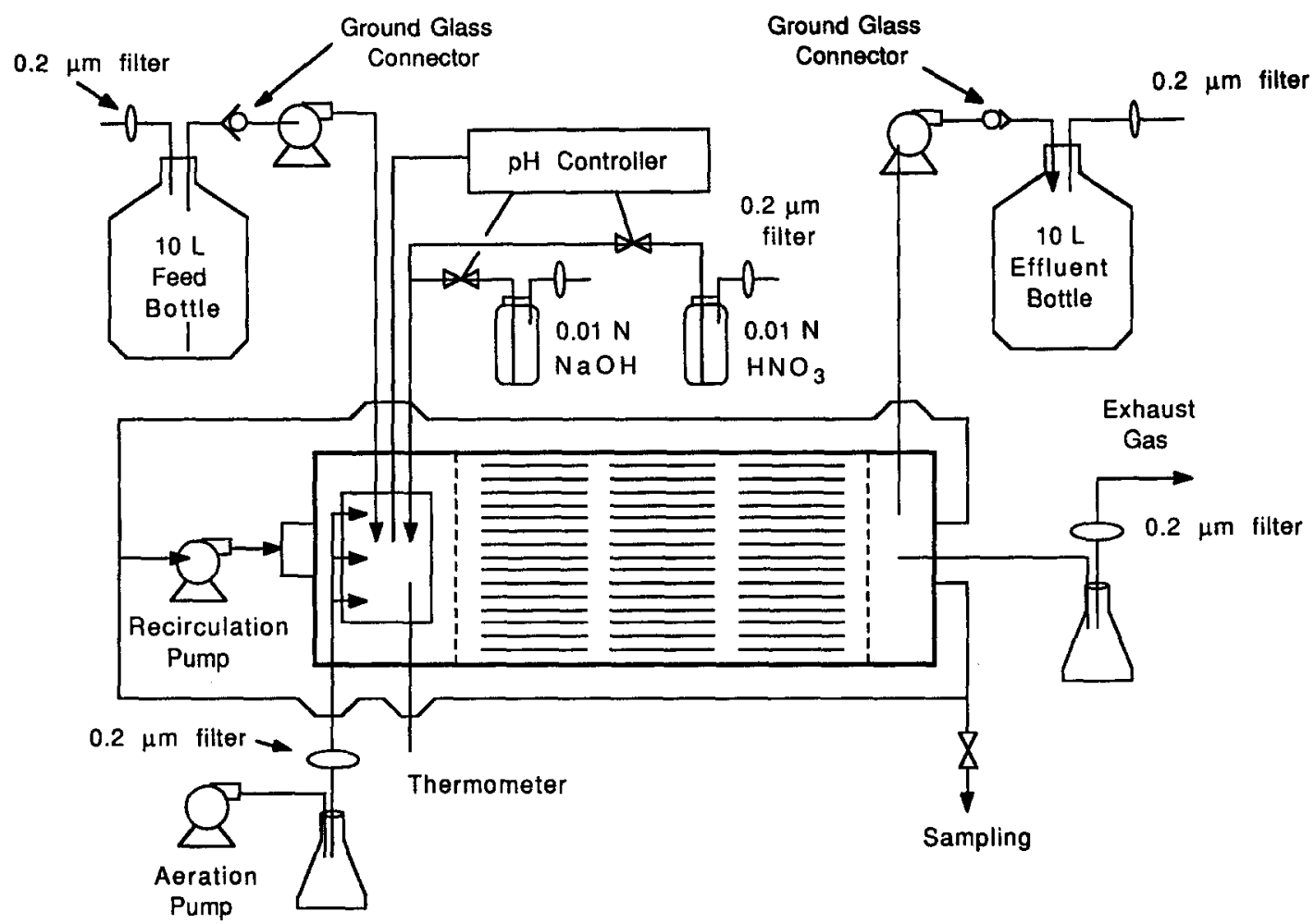

Fig. 2. Biofilm reactor system schematic.

structure can change with changing environmental conditions. The reactor environment was not intended to mimic a complete natural environment, but rather to simulate realistic elements of such a system in order to study relevant mechanisms of trace metal adsorption under controlled conditions.

\section{EXPERIMENTAL}

Biofilm reactor system

The biofilm reactor was constructed from polyethylene and Teflon ${ }^{(\mathbb{A}}$ as described previously (Hsieh et al., 1985). The 1-liter reactor contains 45 glass slides (Fisher Scientific, $51 \times 76 \times 1 \mathrm{~mm})$ in three rows placed parallel to the direction of flow (Fig. 2). Dye-tracer experiments showed uniform plug flow through the reactor chamber, but because the recycle ratio was above 5000 , the reactor could be modeled as a completely mixed system. A pH controller (Chemcadet, Cole Parmer) was used to control addition of $0.01 \mathrm{M}$ solutions of $\mathrm{NaOH}$ and $\mathrm{HNO}_{3}$ to maintain a constant $\mathrm{pH}$ of $6.0 \pm 0.1$. This $\mathrm{pH}$ was chosen to avoid precipitation of lead with phosphate in the medium at a lead concentration of $1 \mu \mathrm{M}$. All experiments in the reactor were conducted at $25 \pm 11^{\circ} \mathrm{C}$. The entire unit was housed in a laminar-flow hood to reduce the risk of bacterial and trace

Table 1. Operating conditions for biofilm reactor experiments with lead

\begin{tabular}{ll}
\hline Total reactor liquid volume & $1.0 \mathrm{liter}$ \\
Feed rate & $1.0-2.0$ liter $/$ day \\
Hydraulic retention time & $12-24 \mathrm{~h}$ \\
Recirculation rate & 8 liter $/ \mathrm{min}$ \\
Reynold's number & 320 \\
Temperature & $25.0 \pm 0.5^{\circ} \mathrm{C}$ \\
Air flow rate & $240 \mathrm{~cm}^{3} / \mathrm{min}$ \\
pH & $6.0 \pm 0.1$ \\
\hline
\end{tabular}

metal contamination. Prior to placement in the reactor, glass slides were precleaned with detergent, soaked for $24 \mathrm{~h}$ in a solution of concentrated $\mathrm{H}_{2} \mathrm{SO}_{4}$ and Nochromix ${ }^{\mathrm{k}}$. (Godax Laboratories, New York) and for $24 \mathrm{~h}$ in 6:1 $\mathrm{H}_{2} \mathrm{O}: \mathrm{HNO}_{3}$ (redistilled $\mathrm{HNO}_{3}$, GFS Chemicals, Columbus, Ohio), and then rinsed in distilled-deionized water $\left(\mathrm{dd}_{2} \mathrm{O}\right)$. Prior to each use, the reactor was cleaned with $6: 1$ $\mathrm{H}_{2} \mathrm{O}: \mathrm{HNO}_{3}(\mathrm{v} / \mathrm{v})$, sterilized with $80 \%$ ethanol at $\mathrm{pH}=1$, and rinsed with 10 liters of sterile $\mathrm{ddH}_{2} \mathrm{O}$ and 10 liters of sterile medium.

Operating conditions for experiments in the biofilm reactor are listed in Table 1. For each run (except controls), the reactor was inoculated with $50 \mathrm{ml}$ of a pure culture of $P$. cepacia 17616 (strain identified by and obtained from $T$. Lessie at the University of Massachusetts) in the logarithmic phase of growth. $P$. cepacia is a rod-shaped, gramnegative obligate aerobe (Bergey's, 1984). $P$. cepacia was previously shown to grow on a dilute, chemically-defined medium and to produce extracellular polymer and attached biofilms (Murgel et al., 1991). The growth medium was originally selected by Murgel et al. (1991) to minimize lead complexation and to ensure against the formation of precipitates that might absorb lead. The medium was modified (MMS-2, Table 2) by increasing the phosphate concen-

Table 2. Defined MMS-2 medium for growth of $P$, cepacia in the biofilm reactor

\begin{tabular}{lc}
\hline Component & Concentration $(\mathrm{mg} / \mathrm{l})$ \\
\hline Pyruvate & 79 \\
$\mathrm{CaCl}_{2} \cdot 2 \mathrm{H}_{2} \mathrm{O}$ & 30 \\
$\mathrm{MgSO}_{4} \cdot 7 \mathrm{H}_{2} \mathrm{O}$ & 35 \\
$\left(\mathrm{NH}_{4}\right)_{2} \mathrm{SO}_{4}$ & 120 \\
$\mathrm{KNO}_{3}$ & 15 \\
$\mathrm{NaHCO}_{3}$ & 0.84 \\
$\mathrm{KH}_{2} \mathrm{PO}_{4}$ & 0.70 \\
Ionic strength adjusted to $0.05 \mathrm{M}$ w/NaNO \\
pH was adjusted to 6.0 before autoclaving \\
\hline
\end{tabular}


tration in the original reported medium (MMS) to ensure that phosphorus was present in excess. Pyruvate was used as the growth substrate at a feed concentration of $79 \mathrm{mg} / 1$. Growth of $P$. cepacia in the MMS-2 medium was confirmed to be carbon limited by measuring growth curves with sodium pyruvate concentrations ranging from 0.01 to $0.5 \mathrm{~g} / \mathrm{l}$ (data not shown). The chemical speciation program MINEQL (Westall et al., 1976) predicted that no precipitates would form under the conditions of the experiments with the modified medium. Water used to prepare the medium and for all other experiments was distilled and deionized and had a resistivity of $18.6 \mathrm{M} \Omega-\mathrm{cm}$. The medium was sterilized by autoclaving at $121-125^{\circ} \mathrm{C}(80 \mathrm{~min}$ for 10 liters, $\mathbf{4 0}$ min for 1 liter).

\section{Iron pretreatment of glais slides}

For some experiments, glass slides were pretreated with sterile suspensions of colloidal iron prior to their placement in the biofilm reactor. Colloidal iron was prepared by precipitating $5 \mathrm{~g} / 1 \mathrm{Fe}\left(\mathrm{NO}_{3}\right)_{3}$ in distilled-deionized water $(\mathrm{pH}=6)$ and stirring for at least 1 month. Conditions of pretreatment were varied to provide a range of surface iron concentrations on the slides. Cleaned glass slides were placed in polypropylene racks (Fluoroware, Inc., Chaska, Minn.) and submerged in 2-liter dilutions of the colloidal iron oxide suspension with concentrations ranging from 10 to $100 \mathrm{mg} \mathrm{Fe} / \mathrm{l}$. The suspensions with the submerged slides were sterilized by autoclaving as described above and then stirred with a magnetic stirrer for $24-96 \mathrm{~h}$. Final surface iron concentrations were determined for test slides by dissolving the surface coating and measuring iron by atomic absorption as described below.

\section{Analyses}

Suspended cell counts in the reactor liquid were measured daily using a particle size analyzer (Coulter Multisizer II, Coulter Electronics, Luton, England). Ten-ml samples were collected from the recycle line and fixed by adding $100 \mu 1$ of $25 \%$ glutaraldehyde (fincl glutaraldehyde concentration = $0.25 \%$ ). After allowing at least $5 \mathrm{~min}$ for fixation, $200 \mu \mathrm{l}$ aliquots of the sample were added to vials and diluted with $20 \mathrm{~g}$ of an isotonic solution (Isoton II, Coulter Diagnostics). The Coulter Counter was equipped with a $30 \mu \mathrm{m}$ orifice and the aperture current was set at $1300 \mu \mathrm{A}$, which allowed observation of the entire size distribution of cells with minimal background counts. Fifty- $\mu 1$ samples were analyzed within $1 \mathrm{~h}$ of collection to avoid errors caused by possible aggregation of cells. Cell counts were compared to plate counts (APHA, 1989) and to direct counts by light microscopy. Direct counts were determined by pipetting a $10 \mu$ sample onto a microscope slide, placing a $18 \times 18 \mathrm{~mm}$ cover slip over the droplet, and counting cells within a $70 \times 70 \mu \mathrm{m}$ ocular reticle grid calibrated at a final magnification of $1260 \times$. A Zeiss Universal (Germany) microscope fitted with $10 \times$ oculars, a $63 \times$ oil inmersion phase contrast objective lens and $2 \times$ optivar system was used for the direct counts.

Biofilm biomass was assayed both by direct microscopic counting of attached cells and by analysis of total oxidizable material using a chemical oxygen demand (COD) analysis of slides removed from the reactor. Direct counts were made using the microscope described above at a magnification of either $800 \times$ or $1260 \times$ by counting cells within a calibrated ocular reticle grid area. The COD of the attached films, which included the contribution of both cells and extracellular polymer, was determined using a modification of the COD technique described in Standard Methods (APHA, 1989). Glass slides removed from the reactor were dipped briefly in distilled water to remove medium and suspended cells and then air dried. The slides were then broken and placed in a $250-\mathrm{ml}$ Erlenmeyer flask. To each flask was added $50 \mathrm{ml}$ distilled-deionized water $\left(\mathrm{ddH}_{2} \mathrm{O}\right), 0.3 \mathrm{~g}$ $\mathrm{HgSO}_{4}, 5 \mathrm{ml}$ sulfuric acid reagent $\left(\mathrm{w} / \mathrm{Ag}_{2} \mathrm{SO}_{4}\right), 25 \mathrm{ml}$ of $0.00417 \mathrm{~N} \mathrm{~K}_{2} \mathrm{Cr}_{2} \mathrm{O}_{7}$, and an additional $70 \mathrm{ml}$ of sulfuric acid reagent. These solutions were refluxed for $2 \mathrm{~h}$, cooled, and titrated with $0.025 \mathrm{~N}$ ferrous ammonium sulfate.

Extracellular, dissolved polymer was analyzed using total organic carbon (TOC) analysis of filtered and dialyzed reactor effluent. Samples $(20 \mathrm{ml})$ from the reactor were filtered through $0.45 \mu \mathrm{m}$ membrane filters (Type HA, Millipore, Bedford, Mass.) and then dialyzed against distilled water using Spectrapor ${ }^{\text {tik }}$ membrane tubing (Spectrum Medical Industries, Los Angeles, Calif.) with a molecular weight cut-off (MWCO) of 6000 to 8000 . The membrane tubing was rinsed with distilled water prior to dialysis to remove leachable organic material that was found to contribute significantly to the measured TOC. For TOC analysis, $1-\mathrm{ml}$ aliquots of the dialyzed sample were analyzed using a Model 700 TOC Analyzer (O-I Corporation, College Station, Tex.). Controls indicated no loss of polymer during filtration or dialysis.

Pyruvate concentrations were determined using a photometric technique with a diagnostic kit obtained from Sigma Chemical Co. (St Louis, Mo, Cat. \# 726).

Lead and iron were analyzed with flameless atomic absorption spectroscopy (FAA) using a Model $\mathbf{4 6 0}$ atomic absorption spectrophotometer (Perkin-Elmer, Norwalk, Conn.) equipped with a Model HGA-2100 graphite furnace (Perkin-Elmer, Norwalk, Conn.). Lead and iron bound to slides was determined by extraction with nitric acid followed by measurement of absorbance of the extract with FAA. Slides were removed from the biofilm reactor, dipped for one second in lead-free MMS-2 medium, and placed individually into $25 \mathrm{ml}$ of $6: 1 \mathrm{H}_{2} \mathrm{O}: \mathrm{HNO}_{3}$. After letting the slides soak in the acid solution for $24 \mathrm{~h}$, the extract solutions were analyzed by FAA. The coefficient of variation for the FAA analyses was below $2 \%$

Lead bound to suspended cells was measured using a filtration technique. At the termination of the reactor runs, a $750-\mathrm{ml}$ effluent sample was collected. Three $200-\mathrm{ml}$ aliquots of this sample were filtered through $0.45 \mu \mathrm{m}$ filters (PVDF, Millipore, with a 47-mm glass holder). For each sample, lead in the filtered solids and filter was extracted with $20 \mathrm{ml}$ of $6: 1 \mathrm{H}_{2} \mathrm{O}: \mathrm{HNO}_{3}$ and analyzed with FAA. The collected filtrate from each sample was passed through a fresh filter, and lead bound to this filter was also extracted and analyzed. This second filter served as a blank that was used to account for lead adsorption to the filter apparatus and/or filter contamination. Lead bound to the second filter was assumed to be equal to that bound to the first filter because the change in aqueous lead concentration after filtration was $<1 \%$. The lead concentration in blanks averaged about $20 \%$ of the total lead measured in reactor effluent samples. The coefficient of variation for the blanks was $20 \%$, which translated to about $5 \%$ error for lead determinations in the samples.

The amount of lead bound to dissolved polymer was estimated by determining the lead concentrations of effluent samples before and after ultrafiltration. Ten-ml samples were filtered with Amicon ${ }^{(\vec{\beta}}$ Centriprep 10 (Danvers, Mass.) ultrafilters, by centrifugation at $1700 \mathrm{~g}$ for $5 \mathrm{~min}$. These ultrafilters had a MWCO of 6000 to 8000 . Samples of the filtered and unfiltered liquid were acidified to $\mathrm{pH} 2$ for storage and then analyzed for lead by FAA. Polymer-bound lead was estimated from the difference between the lead concentration before and after ultrafiltration. Controls indicated that lead adsorption to the filter apparatus was negligible.

\section{Lead adsorption isotherms}

Lead adsorption to glass slides, biofilms and iron coatings was measured in solutions of lead with initial lead concentrations ranging from 0.2 to $2 \mu \mathrm{M}$. Slides with biofilms were prepared in the biofilm reactor and slides with similar pretreatments but without biofilms were prepared and stored in sterile MMS-2 medium. After pretreatment, three slides from each treatment were placed in polypropylene 
racks and submerged into each of five 2-liter solutions with five different lead concentrations. The lead solutions were prepared in MMS-2 medium without pyruvate at $\mathrm{pH} 6$. These solutions were kept in 4-liter polypropylene beakers at $25^{\circ} \mathrm{C}$ and stirred continuously with magnetic stirrers for $20 \mathrm{~h}$. After equilibration, the slides were removed from the solutions and dipped for one second into lead-free MMS-2 medium $(\mathrm{pH}=6)$ to remove any residual lead solution. Lead and iron adsorbed on the slides was extracted by soaking each slide in $25 \mathrm{ml}$ of $6: 1 \mathrm{H}_{2} \mathrm{O}: \mathrm{HNO}_{3}$ for $24 \mathrm{~h}$ with occasional stirring. Extracted lead and iron in these solutions were then analyzed using FAA as described above. The total lead in the equilibrium solutions was also determined by FAA, and the free lead ion concentration was calculated using MINEQL

\section{RESULTS}

\section{Lead distribution in the biofilm reactor}

The biofilm reactor was inoculated with $P$. cepacia 17616 and operated for four continuous-flow runs, each being 4-8 weeks in duration. Each of these runs appeared to be free of microbial contamination, as confirmed by spread plates and microscopical examination. After inoculation, the suspended cell concentration increased to a steady value of about $5.0 \times 10^{7}$ cells $/ \mathrm{ml}$ after the first 10 days of operation. In each run, the reactor was initially operated without lead addition, and after reaching steady conditions, lead was added to the feed at a concentration of $1.2-1.5 \mu \mathrm{M}$. This step change allowed evaluation of the effect of lead on the biological system by monitoring suspended cell counts. The effluent lead concentration gradually increased as the reactor liquid was cycled out of the system and as lead adsorption sites became saturated (Fig. 3). After reaching a constant effluent lead concentration, the amount of lead bound to suspended cells, dissolved polymer and attached films was determined. Lead bound to suspended cells (at $5.0 \times 10^{7}$ cells $/ \mathrm{ml}$ ) accounted for only about one percent of the total lead in the reactor effluent (Table 3). On the basis of the number of cells, lead adsorption was $0.003 \mu \mathrm{mol} \mathrm{Pb} / 10^{10}$ cells, and on the basis of the COD of the suspended cells, lead adsorption was about $0.010 \mu \mathrm{mol} \mathrm{Pb} /$ mequiv COD.

The dissolved polymer concentration at steady state, measured using dialysis and TOC analysis, was

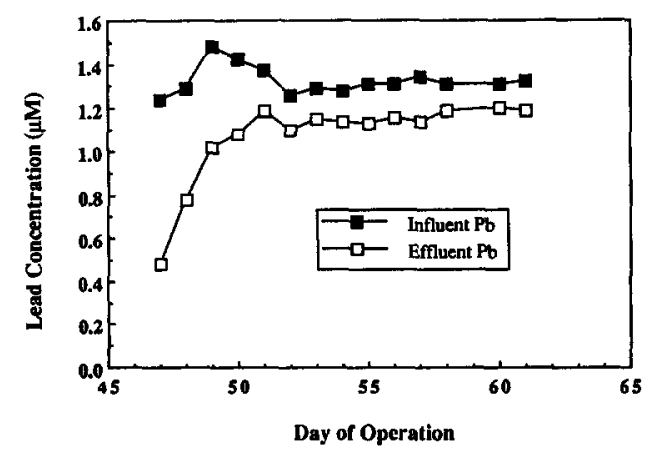

Fig. 3. Influent and effluent lead concentrations during a typical run in the biofilm reactor [same run as in Fig. 7(A)].
Table 3. Biological components of the reactor and lead speciation at termination of biofilm reactor experiments (average of results from two reactor runs*)

\section{Biological system:}

Suspended cells

Dissolved polymer

Residual pyruvate

$5.5+0.2 \times 10^{7}$ cells $/ \mathrm{ml}$

$2.5 \pm 0.25 \mathrm{mg} \mathrm{TOC} / 1$

$1.1 \pm 0.1 \mathrm{mg} / 1$

Lead distribution overall (1.0-liter reactor)

Total lead bound to biofilms/slides $\quad 0.32 \mu \mathrm{mol}$

Total lead in solution and suspension $\quad 1.4 \mu \mathrm{mol}$

Distribution of dissolved and suspended lead (concentrations in $\mu \mathrm{M}$ )

Total lead

Free aquo lead $\dagger$

Suspended Cell-bound lead

Complex $\mathrm{PbSO}_{4}^{\dagger}$

Complex $\mathrm{PbOH}^{+}+$

Complex w/residual pyruvate

Polymer-bound lead

$1.40 \pm 0.11$

1.24

$0.015 \pm 0.004$

0.13

0.017

Negligible

Below detection

* Standard deviation indicated by \pm .

†Determined using MINEQL.

$2.5 \pm 0.25 \mathrm{mg}$ TOC $/ 1$, and at this polymer concentration complexation of lead with polymer was not detected. The steady state pyruvate concentration was $1 \mathrm{mg} / \mathrm{l}$, and lead complexation with pyruvate at this concentration was calculated using MINEQL to also be negligible. Complexation with inorganic ligands (sulfate and hydroxide) accounted for $11 \%$ of the lead in solution (Table 3). Metabolically generated $\mathrm{CO}_{2}$ was controlled through gas exchange with the atmosphere because the reactor was well-aerated. MINEQL modelling was based on an open system with a constant $\mathrm{pH}$ of 6.0 , and under these conditions carbonate and bicarbonate complexes with lead were calculated to be negligible.

Biofilms developed to the extent of approximately $40 \%$ surface coverage on slides in the first row in the reactor and about $30 \%$ surface coverage on slides in the second and third rows (Fig. 2). Surface cell concentrations were estimated using direct microscopic counting to be $4.8 \times 10^{11}$ cells $/ \mathrm{m}^{2}$ in the first row of slides and $2.9 \times 10^{11}$ cells $/ \mathrm{m}^{2}$ in the second and third rows. The chemical oxygen demand (COD) of these biofilms was $52 \pm 7$ mequiv $\mathrm{COD} / \mathrm{m}^{2}$ in the first row and $32 \pm 2$ mequiv $\mathrm{COD} / \mathrm{m}^{2}$ in the second and third rows. The higher cell densities and COD on the first row of slides may have been caused by differences in the fluid dynamics near the inlet of the reactor. This difference was probably not caused by a gradient in substrate concentration because the recycle ratio was very high $(\sim 5000)$.

Significant amounts of lead were bound to the attached biofilms after equilibration with influent lead at a total concentration of $1.4 \mu \mathrm{M}$. The lead concentration on biofilm-coated surfaces ranged from 0.7 to $1.5 \mu \mathrm{mol} \mathrm{Pb} / \mathrm{m}^{2}$, depending on the amount of biofilm developed on the glass surface (Table 4). Using the lead adsorption isotherm determined for the glass slides (see following section), it was estimated that $0.25 \mu \mathrm{mol} \mathrm{Pb} / \mathrm{m}^{2}$ would be adsorbed to the glass substratum. Subtracting this quantity from the total adsorbed lead indicates that $0.5-1.25 \mu \mathrm{mol} \mathrm{Pb} / \mathrm{m}^{2}$ was adsorbed to the attached 
Table 4. Lead bound to surfaces in the bioreactor. ${ }^{*}$ Total effluent $\mathrm{Pb}$ concentration $=1.40 \mu \mathrm{M}$; free $\mathrm{Pb}$ ion concentration $=1.24 \mu \mathrm{M}$

\begin{tabular}{|c|c|c|c|c|c|}
\hline \multirow{3}{*}{$\begin{array}{l}\text { Row in } \\
\text { reactor }\end{array}$} & \multirow{3}{*}{$\begin{array}{l}\mathrm{COD} \text { of biofilm } \\
\text { (mequiv } \mathrm{COD} / \mathrm{m}^{2}\end{array}$} & \multicolumn{4}{|c|}{ Surface lead concentration } \\
\hline & & \multirow{2}{*}{$\begin{array}{c}\text { Total } \\
\left(\mu \mathrm{mol} / \mathrm{m}^{2}\right)\end{array}$} & \multirow{2}{*}{$\begin{array}{c}\text { Glass }{ }^{\dagger} \\
\left(\mu \mathrm{mol} / \mathrm{m}^{2}\right)\end{array}$} & \multicolumn{2}{|r|}{ Biofilm } \\
\hline & & & & $\left(\mu \mathrm{mol} / \mathrm{m}^{2}\right)$ & ( $\mu \mathrm{mol} /$ equiv COD) \\
\hline 1 & $52 \pm 7$ & $1.50 \pm 0.18$ & 0.25 & 1.25 & 24 \\
\hline 2 & $32 \pm 0$ & $0.72 \pm 0.17$ & 0.25 & 0.47 & 15 \\
\hline 3 & $32 \pm 4$ & $0.80 \pm 0.23$ & 0.25 & 0.55 & 17 \\
\hline
\end{tabular}

biofilms. In terms of the COD of the attached films, estimated biofilm lead adsorption was 15 to $24 \mu \mathrm{mol} \mathrm{Pb}$ /equiv COD (Table 4). The total lead bound to biofilms on all of the slides in the reactor was estimated to be $0.32 \mu \mathrm{mol}$. Thus lead bound to biofilms was significant when compared to the total lead in solution $(1.4 \mu \mathrm{mol}$, Table 3$)$. A mass-balance on: lead entering and exiting the reactor suggested that a total of $1 \mu \mathrm{mol}$ of $\mathrm{Pb}$ accumulated in the reactor (in addition to $\mathrm{Pb}$ in solution). This indicates that lead may also have adsorbed to the other reactor surfaces and to attached cells in other parts of the reactor system such as the recycle lines, pump and reactor walls. At steady state, however, this sink for lead in the reactor system would have had no effect on final lead phase distribution.

Effect of iron on lead adsorption in the biofilm reactor

Iron deposits on glass and biofilm surfaces significantly increased lead adsorption. To observe the effect of iron deposits on lead adsorption, the biofilm reactor was operated with a portion of the glass slides pretreated with colloidal iron prior to exposure to lead. The iron pretreatments resulted in final surface iron concentrations of $34.5 \pm 6.8 \mu \mathrm{mol} \mathrm{Fe} / \mathrm{m}^{2}$. Control slides with no iron treatment exhibited final surface iron concentrations of only $0.92 \pm 1.2 \mu \mathrm{mol}$ $\mathrm{Fe} / \mathrm{m}^{2}$. After growing biofilms on the iron-treated and untreated slides and exposing the reactor to an influent lead concentration of $1.4 \mu \mathrm{M}$, lead adsorption was $2.7 \pm 0.3 \mu \mathrm{mol} \mathrm{Pb} / \mathrm{m}^{2}$ on the iron-

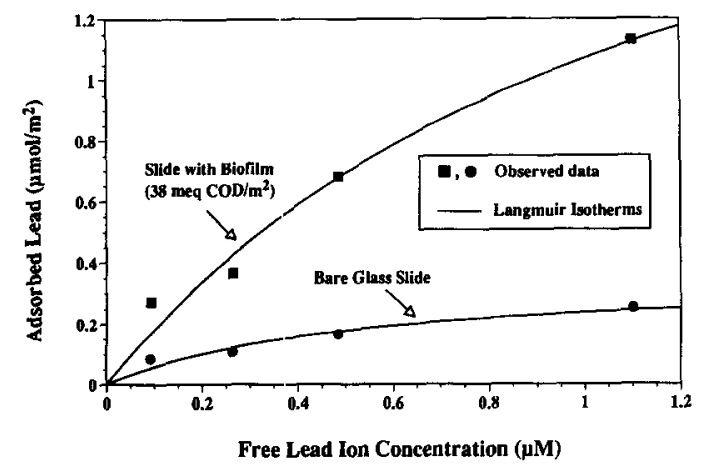

Fig. 4. Effect of biof:lms on lead adsorption to glass surfaces: lead adsorption to biofilm and glass compared to lead adsorption to glass alone. treated slides, but only $1.0 \pm 0.5 \mu \mathrm{mol} \mathrm{Pb} / \mathrm{m}^{2}$ on the untreated slides.

\section{Lead adsorption isotherms}

Lead adsorption to biofilms and iron deposits was further investigated by measuring lead adsorption isotherms for glass slides with and without biofilms and with and without iron pretreatment. To generate these isotherms, the biofilm reactor was used to produce slides with biofilms, and lead adsorption was then measured outside the reactor by equilibrating lead solutions with the variously treated slides. Lead adsorption to the composite of the glass surface and biofilm coating are compared to lead adsorption to glass alone in Fig. 4. The presence of a biofilm (38 mequiv $\mathrm{COD} / \mathrm{m}^{2}$ ) increased lead adsorption by about a factor of five relative to bare glass over a range of lead concentrations from 0.1 to $1.1 \mu \mathrm{M}$.

To investigate lead adsorption to iron deposits, lead adsorption isotherms were determined for sterile slides treated with colloidal iron oxide (no biofilm). The effect of iron on lead adsorption to slides depended on the amount of iron deposited. For example, with a surface iron concentration of $7 \mu \mathrm{mol}$ $\mathrm{Fe} / \mathrm{m}^{2}$, lead adsorption approximately doubled relative to bare glass (Fig. 5).

Figures 4 and 5 compare lead adsorption of composite surfaces (glass plus biofilm, and glass plus iron) to that of glass alone. To determine lead adsorption isotherms individually for $P$. cepacia biofilms and iron oxide, adsorption to bare slides was subtracted from the total lead adsorbed to the composite

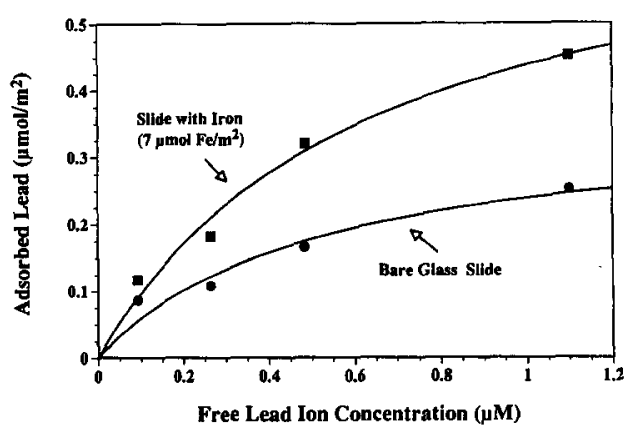

Fig. 5. Effect of iron deposits on lead adsorption to glass surfaces: lead adsorption to iron-treated slides compared to lead adsorption to glass alone. 
(A)

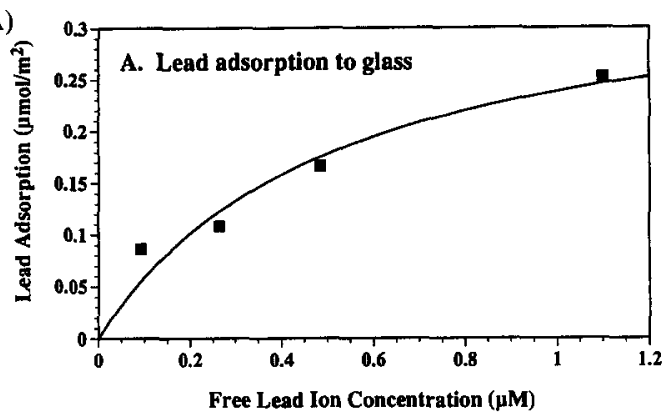

(B)

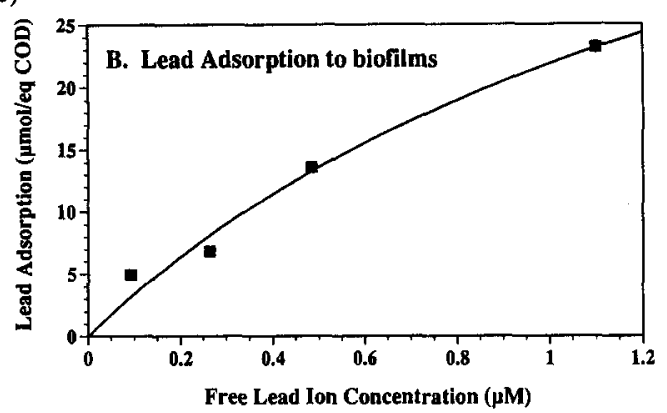

(C)

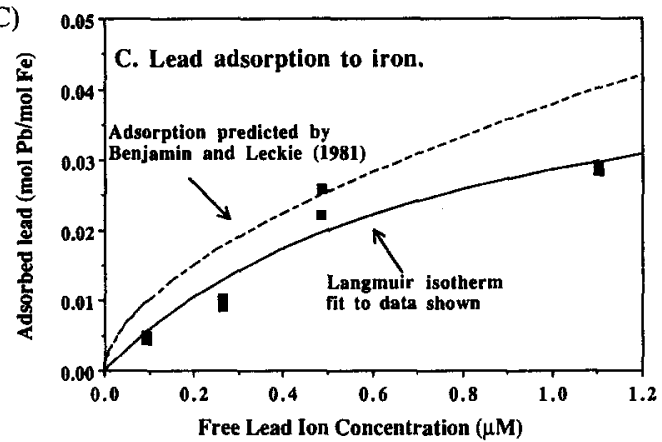

Fig. 6. Langmuir isotherms for lead adsorption to individual constituents of the multi-component attached films. (A) Bare glass, (B) biofilm, (C) iron. Adsorption data for (B) and $(C)$ were obtained by subtracting predicted adsorption to glass alone [from (A)]. Langmuir isotherms were obtained by non-linear least squares curve-fitting (Delta $\mathrm{Graph}^{\text {ik }}$ ), and Langmuir parameters are listed for each isotherm in

$$
\text { Table } 5 \text {. }
$$

surfaces. Lead adsorption to glass slides over the concentration range of interest followed a Langmuir isotherm [Fig. 6(a) and Table 5]. By subtracting the lead adsorption predicted with this isotherm, an adsorption isotherm for bacterial cells in the biofilm was generated [Fig. 6(b) and Table 5]. Lead adsorption to iron deposits was measured for a range of iron surface concentrations from 1 to $60 \mu \mathrm{mol} \mathrm{Fe} / \mathrm{m}^{2}$. Adsorption to iron was normalized by calculating the molar ratio of lead to iron, resulting in the adsorption isotherm shown in Fig. 6(c) and summarized in Table 5. Measured adsorption to iron was similar to adsorption to amorphous iron oxides reported by Benjamin and Leckie (1981) [Fig. 6(c)]. The predictive capability of these isotherms is evaluated in the discussion section.
Table 5. Langmuir parameters for lead adsorption to components of the biofilm reactor surfaces

\begin{tabular}{lccc}
\hline Component & \multicolumn{1}{c}{$\Gamma_{\max }{ }^{*}$} & $K(1 / \mu \mathrm{mol} \mathrm{Pb}) \dagger$ & $r^{2}$ \\
\hline Glass & $0.36 \mu \mathrm{mol} \mathrm{Pb} / \mathrm{m}^{2}$ & 1.95 & 0.936 \\
Biofilm & $56 \mu \mathrm{mol} \mathrm{Pb} /$ equiv COD & 0.64 & 0.978 \\
Iron deposits & $50 \mu \mathrm{mol} \mathrm{Pb} / \mathrm{mol} \mathrm{Fe}$ & 1.32 & 0.910 \\
\hline
\end{tabular}

${ }^{*} \Gamma_{\text {max }}=$ maximum lead adsorption.

$\dagger K=$ adsorption equilibrium constant.

\section{Biofilm-iron interactions}

Indirect effects of iron on lead distribution via influences of iron on the biological system were also investigated. Possible influences that were evaluated were effects of iron on nutrition and cell deposition rate. Iron mitigation of lead toxicity is another potentially significant interaction, and this is discussed in the next section.

Experiments in shake flasks as well as in the biofilm reactor indicated that iron was not a limiting nutrient for $P$. cepacia. Steady state suspended cell concentrations in the biofilm reactor were not affected by the presence of iron as adsorbed deposits (Fig. 7).

Initial biofilm accumulation rates in the reactor were higher on glass slides pretreated with iron than on slides receiving no pretreatment. During the first 13 days after inoculation, the presence of colloidal iron on the glass surfaces increased the amount of biofilm formed by $41 \%(\mathrm{SD}=4 \%)$. However, 23 days after inoculation, the quantity of biofilm formed was similar on slides with and without adsorbed colloidal iron.

(A)

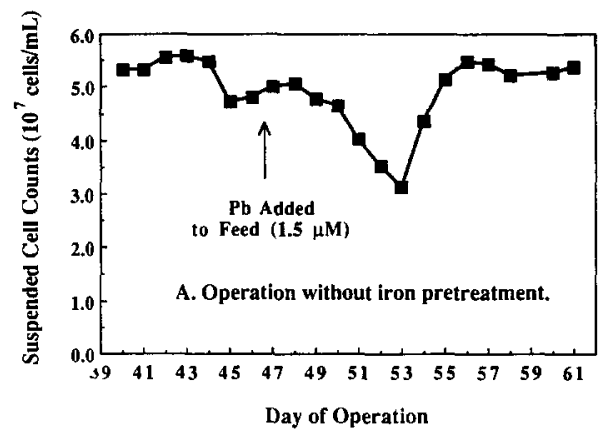

(B)

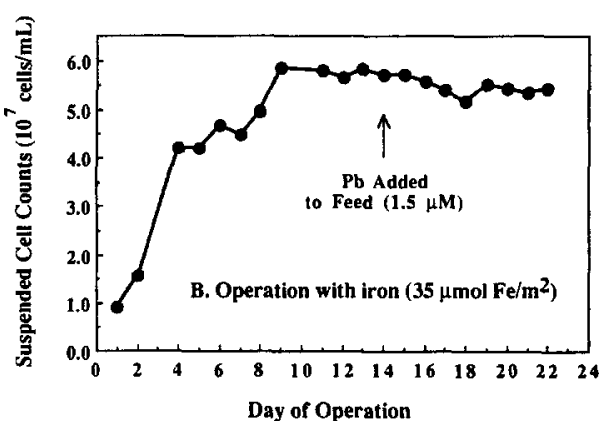

Fig. 7. Cell concentrations during operation of the biofilm reactor. (A) Operation without iron pretreatment of slides. (B) Operation with iron pretreatment of slides. 


\section{Effect of lead on P. cepacia growth}

Toxicity of lead to $P$. cepacia in the biofilm reactor was indicated by a decrease in the concentration of suspended cells after introduction of lead to the system [Fig. 7(a)]. After introduction of lead to the reactor feed, the effluent lead concentration gradually increased to a constant value as lead-free medium was flushed from the reactor and lead adsorption sites in the reactor became saturated (Fig. 3). When the effluent lead concentration reached about $1-1.1 \mu \mathrm{M}$ ( 3 days after introducing lead to the feed), cell numbers decreased from $5 \times 10^{7}$ to $3 \times 10^{7}$ cells $/ \mathrm{ml}$ over the course of a few days. Interestingly, the number of cells then increased to pre-lead levels without any reduction in effluent lead concentration [Fig. 7(a)]. This recovery indicates the possible induction of some form of biological mechanism for overcoming lead toxicity. When iron was added to the reactor in the form of iron pretreated slides, toxic effects of lead toxicity were not observed. Cell numbers remained nearly constant at $5 \times 10^{7}$ cells $/ \mathrm{ml}$, even as the effluent lead concentration increased above $1.1 \mu \mathrm{M}$ [Fig. 7(b)].

Inhibition of $P$. cepacia growth by lead was further verified by a series of experiments in shake flasks. These experiments indicated an $\mathrm{IC}_{50}$ of $0.7 \mu \mathrm{M} \mathrm{Pb}^{2+}$ (free aquo $\mathrm{Pb}^{2+}$ concentration at which growth rate is reduced to $50 \%$ of its uninhibited value). No growth was observed for lead concentrations of $10 \mu \mathrm{M}$ and greater.

\section{DISCUSSION}

\section{Biofilm composition}

At the end of the lead equilibration experiments in the biofilm reactor (with total $[\mathrm{Pb}]=1.4 \mu \mathrm{M}$, and $\left.\left[\mathrm{Pb}^{2+}\right]=1.24 \mu \mathrm{M}\right)$, total lead binding to biofilms without iron was estimated to be $0.5-1.25 \mu \mathrm{mol}$ $\mathrm{Pb} / \mathrm{m}^{2}$. This lead binding was probably due to the sum of adsorption to attached cells and complexation by surface-associated exopolymers. The total COD measured for these biofilms (cells + polymer) was between 32 and 52 mequiv $\mathrm{COD} / \mathrm{m}^{2}$. Based on the measured COD of suspended cells $(0.32 \pm 0.04$ mequiv COD $/ 10^{10}$ cells), if attached cells exerted the same COD per cell as suspended cells, the attached cells (at a surface concentration of $2.9-4.8 \times 10^{11}$ cells $/ \mathrm{m}^{2}$ ) would be expected to exert a COD of $9.3-15$ mequiv $\mathrm{O}_{2} / \mathrm{m}^{2}$. By this calculation, attached cells would account for only about $30 \%$ of the total oxidizable material measured for the biofilms. Presumably, the remaining $70 \%$ of the organic material was extracellular polymer produced by attached cells, indicating that significantly more extracellular polymer is associated with attached cells than with suspended cells. Similarly, other researchers recently studied exopolysaccharide synthesis of a bacterium and reported that attached cells produced five times more extracellular polysaccharide than free-living cells of the same culture (Vandevivere and Kirchman, 1993).

Based on the observed adsorption of lead to suspended cells $\left(0.003 \mu \mathrm{mol} \mathrm{Pb} / 10^{10}\right.$ cells), and the surface concentration of attached cells $\left(2.9-4.8 \times 10^{11}\right.$ cells $/ \mathrm{m}^{2}$ ), adsorption to attached cells would be expected to result in only $0.09-0.14 \mu \mathrm{mol} \mathrm{Pb} / \mathrm{m}^{2}$ in the biofilm reactor experiments. This accounts for only $10-20 \%$ of the total lead adsorption measured for the biofilms. Therefore, lead binding to surfaceassociated extracellular polymer may be significantly greater than adsorption to attached cells alone, and further study of the biofilm composition and adsorption to its constituents is warranted.

\section{Predictive capability of isotherms}

The ability of the Langmuir adsorption isotherms of individual constituents to predict total lead adsorption to the composite surfaces was tested using measurements of total adsorption to composite surfaces in the biofilm reactor and in separate adsorption experiments. Total lead adsorption was predicted based on the assumption that adsorption to the multi-component film was additive. Implicit in this assumption is that adsorption site masking, as reported by Honeyman and Santschi (1988) is not significant under these conditions. The hypothesis used here was that:

$$
\Gamma_{\text {glass }+\mathrm{Fe}+\text { biofilm }}=\Gamma_{\text {glass }}+\Gamma_{\mathrm{Fe}}+\Gamma_{\text {biofilm }},
$$

where the term on the left is the total measured adsorbed lead per unit area, and the terms on the right are predicted lead absorption to each constituent as calculated from Langmuir isotherms.

Lead adsorption measured for multi-component surfaces is compared to the sum of adsorption predicted for each component in Fig. 8. These data were obtained by equilibrating slides removed from the biofilm reactor with solutions of lead in MMS-2 medium (without pyruvate) at $\mathrm{pH} 6$ over a range of lead ion concentrations. For lead concentrations from 0.5 to $1.2 \mu \mathrm{M}$, the predicted adsorption was

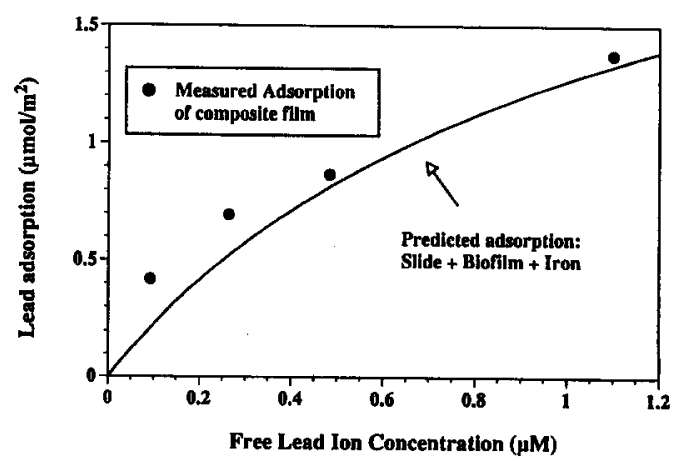

Fig. 8. Lead adsorption to glass slides with biofilms and iron deposits: comparison of lead adsorbed to composite surface to lead absorption predicted by summing predicted adsorption to surface constituents. 
Table 6. Prediction of lead adsorption to multi-component surfaces in the biofilm reactor using lead adsorption isotherms for glass, biofilms and iron

\begin{tabular}{|c|c|c|c|c|c|}
\hline \multicolumn{6}{|c|}{$\begin{array}{l}\text { Biofilm reactor conditions: } \\
\text { Final total lead concentration }=1.40 \mu \mathrm{M} \\
\text { Final calculated free lead ion concentration }=1.24 \mu \mathrm{M}\end{array}$} \\
\hline \multirow{2}{*}{$\begin{array}{l}\text { Iron conc. } \\
\left(\mu \mathrm{mol} \mathrm{Fe} / \mathrm{m}^{2}\right)\end{array}$} & \multirow{2}{*}{$\begin{array}{l}\text { Measured adsorbed } \\
\text { lead }\left(\mu \mathrm{mol} \mathrm{Pb} / \mathrm{m}^{2}\right)^{*}\end{array}$} & \multicolumn{4}{|c|}{ Predicted Adsorbed Lead $\left(\mu \mathrm{mol} \mathrm{Pb} / \mathrm{m}^{2}\right)$} \\
\hline & & Glass & Biofilm $†$ & Iron & Total \\
\hline - & $1.0 \pm 0.3$ & 0.25 & 0.94 & - & 1.2 \\
\hline 3.9 & $1.4 \pm 0.3$ & 0.25 & 0.94 & 0.12 & 1.3 \\
\hline 34.5 & $2.7 \pm 0.3$ & 0.25 & 0.94 & 1.08 & 2.3 \\
\hline
\end{tabular}

* Standard deviation indicated by \pm

+Based on biofilm coverage of 38 mequiv $\operatorname{COD} / \mathrm{m}^{2}$

within $5 \%$ of measured values. However, at low lead concentrations $(0.1-0.3 \mu \mathrm{M})$ the multi-component films appeared to have adsorbed more lead than was predicted by summing the constituent contributions. The difference between prediction and observation at low lead concentrations may have been caused, in part, by less accurate lead concentration measurements at low concentrations.

Langmuir adsorption isotherms for glass, iron and biofilms were also used to predict lead adsorption to multi-component surfaces during direct adsorption experiments in the biofilm reactor. Predicted adsorption was within experimental error compared to that measured at the termination of the reactor runs (Table 6).

It might be argued that the additivity of lead adsorption presented here is an artifact of the fact that adsorption to individual components was calculated by subtracting adsorption to the other components. However, lead adsorption to biofilms and iron were determined separately, requiring only the subtraction of lead adsorption to the glass substrate in order to calculate adsorption to each of these components. Under most of the conditions of these experiments, lead adsorption to glass was relatively small compared to that of biofilms or iron deposits, so that error introduced by subtracting inaccurate adsorption to glass would be small. Further, lead adsorption to iron measured in this work agrees with published data for lead adsorption to amorphous iron (Benjamin and Leckie, 1981).

\section{Significance of suspended and dissolved biogenic materials}

In contrast to the strong effect of biofilms on lead adsorption, suspended cells and dissolved polymer had little effect on the distribution and speciation of lead in the bulk reactor liquid. Polymer-bound lead in solution was not detectable in these experiments, and lead bound to suspended cells accounted for only one percent of the total lead in solution. In comparison, lead adsorbed to surface coatings of $P$. cepacia accounted for about $15 \%$ of the total lead in the system.

The amount of organic material in solution or suspension in these experiments was limited by the amount of growth substrate (pyruvate) provided.
Previous laboratory studies have used higher concentrations of carbon, resulting in greater quantities of lead bound to suspended cells (Hsieh, 1988). Natural aquatic environments tend to be oligotrophic with very low concentrations of growth substrates. Thus, the low concentrations of cell-bound and polymerbound lead observed in these experiments might be expected to prevail in natural environments. However, over long time periods the role of biogenic organic materials in transport of trace metals to sediments is probably significant.

\section{Lead inhibition of $\mathrm{P}$. cepacia growth}

Lead inhibited the growth of $P$. cepacia in the biofilm reactor at total lead concentrations of $1-2 \mu \mathrm{M}$, and an $\mathrm{IC}_{50}$ (inhibitory concentration that

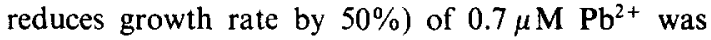
determined in shake-flask experiments. Because of the low concentrations of nutrients in the MMS-2 medium employed, $0.7 \mu \mathrm{M} \mathrm{Pb}^{2+}$ corresponds to a total $\mathrm{Pb}$ concentration of only $0.9 \mu \mathrm{M}$. In richer media, the total lead concentration could be expected to be one or two orders of magnitude greater than the concentration of the free aquo $\mathrm{Pb}^{2+}$ ion because of complexation and/or precipitation with media components. Thus determinations of lead toxicity to bacteria in rich media would be expected to result in observed toxicity at much higher total lead concentrations than those observed in the present work

Lead inhibition of $P$. cepacia was apparently mitigated by the presence of iron deposits on reactor surfaces. Iron deposits may have reduced the availability of lead to the bacteria by sequestering lead, or alternatively iron may have facilitated a biological mechanism to avoid lead toxicity. Dissolved iron may have competed with lead for uptake sites on bacterial cells. Similar competition has been reported for other aquatic organisms such as phytoplankton (Foster and Morel, 1982; Sunda et al., 1981).

Lead inhibition of growth should be considered in developing growth models for pure cultures of $P$. cepacia with lead present. However, in natural environments mixed cultures may be expected to be more resilient to such toxic effects. Further, the mitigation of toxicity by the presence of iron might also be expected to occur in natural systems. 


\section{Iron-biofilm interactions}

Indirect influence of iron on the biological system via nutrition was not significant under the conditions of these experiments. The presence of iron increased initial biofilm accumulation rates, but did not affect long-term biofilm coverage. Other interactions between the biofilms and iron that could affect lead adsorption are effects of the biofilms on deposition and retention of colloidal iron on surfaces. It was observed during the experiments reported here that the presence of a biofilm led to increased retention of iron previously deposited by iron pretreatments. In one experiment, slides with similar iron pretreatments were placed either into the biofilm reactor where attached films were allowed to grow on the slides or into sterile medium. In most cases, slides with biofilms retained significantly more iron than slides that were stored in sterile medium. Biofilm enhancement of iron deposition was not considered in this research, but is being evaluated in other ongoing experiments with the reactor (Lo et al., 1996).

\section{CONCLUSIONS}

The presence of surface coatings of adherent bacteria and iron contributed to significant adsorption of lead to reactor surfaces. The strongest effect exerted by the biological system on lead distribution in these experiments was that of lead adsorption by the biofilms. Biofilms with 38 mequiv $\mathrm{COD} / \mathrm{m}^{2}$ of total oxidizable material increased lead adsorption relative to bare glass by a factor of five. These biofilms covered only $20-30 \%$ of the total available glass surface area, and a greater effect would be expected for complete biofilm coverage. Because surfaces in natural aquatic systems are usually completely coated with biofilms, these results are an indication of the importance of the effect of biofilms on lead distribution.

COD measurements indicated that attached cells in the biofilms contained significant quantities of extracellular organic material. This material, presumed to be polysaccharides, contributed to additional lead adsorption. In future work, extracellular materials in the biofilm should be studied more extensively in order to incorporate the binding of lead by these materials into modeling of lead distribution.

Iron deposits increased lead adsorption up to a maximum value of $0.05 \mathrm{~mol} \mathrm{~Pb} / \mathrm{mol} \mathrm{Fe}$. Adsorption isotherms determined with these experimental data agree with previously published isotherm data for amorphous iron oxide (Benjamin and Leckie, 1981). Surface iron concentrations of $30 \mu \mathrm{mol} \mathrm{Fe} / \mathrm{m}^{2}$ induced lead adsorption comparable to that of a biofilm with 38 mequiv $\mathrm{COD} / \mathrm{m}^{2}$ of oxidizable material. The relative contributions of iron compared to attached cells in influencing adsorption of lead to surfaces in natural aquatic environments will depend on the relative amounts of iron and cells present, and the isotherms presented here can be used to estimate these contributions. Total lead adsorption by the composite glass/iron/biofilm surface could be estimated by summing the predicted lead adsorption to each component using Langmuir adsorption isotherms.

Interactions between iron oxides and biofilms may also be important. For example, in the present work iron deposits were found to increase initial biofilm formation rates and biofilms increased the retention of iron deposits on the pretreated slides. Additional study of these phenomena to determine their significance in natural environments appears warranted.

Binding of lead to suspended cells and dissolved polymer accounted for only one percent of the lead in solution under the conditions of the biofilm reactor experiments. In many natural aquatic environments similarly low organic concentrations may exist, but the cumulative effect of lead adsorption to suspended cells followed by their deposition onto surfaces may be significant over long periods of time.

Toxicity of lead to $P$. cepacia significantly reduced suspended cell concentrations in the biofilm reactor for lead concentrations of $1-2 \mu \mathrm{M}$. However, this effect was temporary and was observed to be mitigated by the presence of iron.

While the reactor system employed in these experiments incorporated many elements of natural aquatic environments, it is still a very simplified simulation. A unique feature of the present work is that it included a well-defined composite system that included a biological component. This system permits the development of a mechanistic model for the growth, attachment and detachment of the biological system and their effect on lead adsorption. The creation of such a model is an objective of our ongoing research. This work will lay the foundation for expanding modelling to incorporate more variables that may exist in natural environments.

Acknowledgements - This work was supported by the National Science Foundation, under Grant \# BCS-91-00209. The authors are grateful for the technical assistance of Carolyn Acheson, Sharon Best, Jyh-Herng Chen, Rhea Garen, Ronald Taticek, and Cameron Willkens.

\section{REFERENCES}

APHA (1989) Standard Methods for the Examination of Water and Wastewater, 17 th edn. American Public Health Association, American Water Works Association and Water Pollution Control Federation.

Balistrieri L. S. and Murray J. W. (1983) Metal solid interactions in the marine environment: Estimating apparent equilibrium binding constants. Geochim. Cosmochim. Acta 47, 1019.

Benjamin M. M. and Leckie J. O. (1981) Multiple-site adsorption of $\mathrm{Cd}, \mathrm{Cu}, \mathrm{Zn}$, and $\mathrm{Pb}$ on amorphous iron oxyhydroxide. J. Colloid Interface Sci. 79, 209-221

Bergey's Manual of Determinant Bacteriology (1974) (Edited by Buchanan R. E. and Gibbons N. E.), 8th edn. William \& Wilkins, Baltimore.

Brundin N. H. and Nairis B. (1972) Alternate sample types in regional geochemical prospecting. J. Geochem. Explor. 1, 7-46. 
Carpenter R. H., Pope T. A. and Smith R. L. (1975) Fe-Mn oxide coatings in stream sediment geochemical surveys. J. Explor. Geochem. 4, 349-363.

Cooper B. S. and Harris R. C. (1974) Heavy metals in organic phases of river and estuarine sediment. Mar. Pollut. Bull. 5, 24-26.

Corpe W. A. (1975) Metal-binding properties of surface materials from marine bacteria. Dev. Ind. Microbiol. 11, 402-412.

Davis J. A. (1982) Adsorption of natural dissolved organic matter at the oxide/water interface. Geochim. cosmochim. Acta 46, 2381-2393.

Davis J. A. and Leckie J. O. (1978) Effect of adsorbed complexing ligands on trace metal uptake by hydrous oxides. Envir. Sci. Technol. 12, 1309-1315.

Foster P. L. and Morel F. M. M. (1982) Reversal of cadmium toxicity in a diatom: an interaction between cadmium activity and iron. Limnol. Oceanogr. 27, $745-752$.

Ghiorse W. C. (1984) Biology of iron- and manganese-depositing bacteria. A. Rev. Microbiol. 38, 515-550.

Harvey R. W. and Leckie J. O. (1985) Sorption of lead onto two Gram-negative bacteria in seawater. Mar. Chem. 15, 333-344.

Honeyman B. D. and Santschi P. H. (1988) Metals in aquatic systems. Envir. Sci. Technol. 22, 862-871.

Hsieh K. M. (1988) The growth and attachment of a biopolymer producing Pseudomonas species and the characterization of its interactions with a toxic trace metal. Ph. D. thesis, Cornell University.

Hsieh K. M., Lion L. W. and Schuler M. L. (1985) Bioreactor for the study of defined interactions of toxic trace metals and biofilms. Appl. envir. Microbiol. 50, 1155-1161

Hunter K. A. and Liss P. S. (1979) The surface charge of suspended particles in estuarine and coastal waters. Nature 282, 823-825.

Jenne E. A. (1968) Controls on $\mathrm{Mn}, \mathrm{Co}, \mathrm{Ni}, \mathrm{Cu}$ and $\mathrm{Zn}$. Concentrations in soil and water: the significant role of hydrous $\mathrm{Mn}$ and $\mathrm{Fe}$ oxides. Trace Inorganics in Water, pp. 337-387. American Chemical Society, Washington, D.C.

Kruaskopf K. B. (1956) Factors controlling the concentration of thirteen rare metals in seawater. Geochim. cosmochim. Acta 9, 1-24.

Lion L. W. and Rochlin K. L. (1989) Adsorption of Pb(II) by a marine bacterium: the effect of cell concentration and pH. Estuar. Coastal Shelf Sci. 29, 11-22.

Lion L. W., Altmann R. S. and Leckie J. O. (1982)

Trace-metal adsorption characteristics of estuarine par- ticulate matter: evaluation of contributions of $\mathrm{Fe} / \mathrm{Mn}$ oxide and organic surface coatings. Envir. Sci. Technol. 16, 660-666.

Lion L. W., Shuler M. L., Hsieh K. M. and Ghiorse W. C. (1988) Trace metal interactions with microbial biofilms in natural and engineered systems. CRC Crit. Rev. Envir. Control 17, 273-306.

Lo W., Nelson Y. M., Lion L. W., Shuler M. L. and Ghiorse W. C. (1996) Deposition of colloidal iron onto a biofilm surface: determination of the particle size distribution of colloidal iron (III) oxyhydroxide in the presence of suspended bacterial cells. Wat. Res. Submitted.

Luoma S. N. and Bryan G. W. (1981) A statistical assessment of the form of trace metals in oxidized estuarine sediments employing chemical extractants. Sci. Total Envir. 17, 165-196.

Murgel G., Lion L. W., Acheson C., Shuler M. L., Emerson D. and Ghiorse W. C. (1991) An experimental apparatus for selection of adherent microorganisms under stringent conditions. Appl. envir. Microbiol. 57, 1987-1996.

Rudd T., Sterritt R. M. and Lester J. N. (1984) Complexation of heavy metals by extracellular polymers in the activated sludge process. J. Wat. Pollut. Control Fed. 56, 1260-1268.

Sigg L. (1985) Metal transfer mechanisms in lakes: the role of settling particles. Chemical Processes in Lakes, pp. 283-310. Wiley, New York.

Sunda W. G., Barber R. T. and Huntsman S. A (1981) Phytoplankton growth in nutrient rich seawater: Importance of copper-manganese cellular interactions. J. Mar. Res. 39, 567-573.

Tipping E. and Cooke D. (1982) The effects of adsorbed humic substances on the surface charge of geothite in freshwaters. Geochim. cosmochim. Acta 46, 75-80.

Turekian K. K. (1977) The fate of metals in the oceans. Geochim. cosmochim. Acta 41, 1139-1144.

Vandevivere P. and Kirchman D. L. (1993) Attachment stimulates exopolysaccharide synthesis by a bacterium. Appl. envir. Microbiol. 59, 3280-3286.

Westall J. C., Zachary J. L. and Morel F. M. M. (1976) MINEQL, a computer program for the calculation of chemical equilibrium composition of aqueous systems. Technical Note 18. Department of Civil Engineering, Massachusetts Institute of Technology, Cambridge, Mass.

Whitney P. R. (1975) Relationship of manganese-iron oxides and associated heavy metals to grain size in stream sediments. J. Explor. Geochem. 4, 251-263. 